\title{
Relevancy of foreign employment in the present context of Nepal
}

\author{
Uttam Lal Joshi \\ Lecturer of Economics \\ Makawanpur Multiple Campus \\ M. Phil. in Economics (Scholar) \\ Nepal Open University \\ E-mail:uttamjoshi88@gmail.com
}

\begin{abstract}
There is more charm on foreign employment since decades. Due to lack of employment opportunities in public and private sectors, Nepali people are motivated to go foreign countries for job opportunities. Handsome salaries, respected life, relief from poverty and fulfillment of needs - these are the common motivators that lead people for foreign employment. This can be right in one aspect but there are a lot of evidences and scenarios that shows foreign employment is not so easier and fruitful as it is thought. Foreign employees have to face many more difficulties and obstacles in foreign countries that one will explain after his return to home country. So the income from their hard labor must be utilized in proper sectors. Various data in this study show the foreign employment is not so safe. Here, the time series data from 2002/03 to 2019 are taken for the study of the relationship between remittance and investment. The regression analysis with P-value 0.000at 5\% significant level ( $\alpha=$ 0.05) which shows that the remittance from foreign employment has been used in investment anyway. It will help to find the productivity, relevance and proper use of the income from foreign employment.
\end{abstract}

Key words: foreign employment; investment; remittance

\section{Introduction}

Many workers from Nepal going abroad are no doubt young, energetic, laborious and enthusiastic. They do hard work for earning large remittance income to support the family (Gaudel, 2006). There is more charm on foreign employment since decades due to lack of employment opportunities in public and private sectors, Nepali people are motivated to go foreign countries for job opportunities. Handsome salaries, respected life, relief from poverty and fulfillment of needs - these are the common motivators that lead people for foreign employment that became the dream of younger 
Nepali citizens after their formal education, even they will not complete their formal education for these aims. Various data indicates that foreign remittance has helped increase income sizably reduce poverty and inequality marginally (Wagle, 2012). Every year thousands of Nepali citizens go abroad for job opportunities. About 5,00,000 labor permits were issued in the fiscal year 2015/2016 to Nepali workers for seeking foreign employment - out of which $96 \%$ permits were issued for male workers show there is huge charm in foreign employment for Nepali citizens. There has been an increasing demand for the Nepali workers in international labor marketsin the recent years.Among the various uses of remitted fund vary by reducing poverty, creating economic security and enhancing social status within the household and the community. Remittances have been playing pivotal role by relaxing foreign exchange constraint, increasing contribution to GDP and strengthening the balance of payment situation of the country(Thagunna and Acharya, 2013)..

A lot of evidences and scenarios show foreign employment is not so easier and fruitful as we think because foreign employees have to face many more difficulties and obstacles that one will explain after his/her return to home country. A lot of foreign- goers are now self- employed and they are in practice of improving better standard of living realizing they have to respect every job available in the country and labor in home country is more valuable than foreign country. Their feeling, thinking and attitude towards labor completely change after their return and learn to live with own labor, effort and sweat after return in home country.

The purpose of the study is to find out the relationship between remittance and investment in the present context of Nepal where millions of people are in the abroad for employment. Among them only a few portions of people can have better job but lots of them are in the tragedy of life, lots of them have lost their life during job and a large number of foreign goers are living with maimed and handicapped life. Is foreign employment safe for foreign goers? The foreign employment is not easy and safe for themand a care should be taken to choose foreign employment as first destination so I want to study- do people use this income in investment purposes? Mere consumption of this income means no seriousness in the hard labor, toil and sweat in foreign countryso the income from remittance should be used in proper sectors and the individual and the country should be benefitted from this income.

Foreign employment became the first choice of young Nepali citizen in the present context where a large number of people are in the foreign employment but 
here are some research questions that I want to have answer from the study. First, the major question of the study is,-Is foreign employment safe and is it productive for the sake of the country? In other words whether the foreign employment if in the favor of the people and the country?

Second, the sub question is -Does the remittance income have positive relationship with investment? Here the study is focused on finding out if the remittance is used in the investment of the country?

Third, the study aims at finding out whether the foreign employment is safe or not. So the question is - Is foreign employment relevant?

People headed for foreign employment due to lack of employment opportunities in Nepal and the numbers of foreign goers are increasing every year. They labor hard there and send their income in the home country even their lives are not secured in the foreign country. Various researches show the remittance income is not properly used. A study should be done to find the real situation of this income so the study will help to find out the real use of remittance income in the home country.

\section{A Brief Literature Review}

There are various researches done on foreign employment and remittance in which one research done by Prof. Bijay Shrestha shows that at a time when all the economic indicators in the country are not favorable remittance have played vital role in maintaining macro-economic stability and keeping the economy afloat. In the next research study shows that remittance inflow is increasing nowadays but they are used in consumption of land, building, education and service (Dhakal, B.,2013).In the research by Daniela Glocker and Victor Steiner shows that the previous ( long- term) unemployment significantly increases entry rates into self- employment for both men and women ( Glocker and Steiner, 2007). Next research by Chandan Sapkota shows that remittance induced Dutch desease effects and policy laxity to improve investment climate in Nepal (Sapkota,C. 2013). Nunley explains the responsibilities of foreign employment should not be viewed lightly (Nunley,R. L. 1971).Likewise Uprety D. P. (2017) and Srivastava, N. L., \& Chaudhary, S. K. (2007) noted that remittance plays major role in economic development because it increases consumption expenditure.

In the paper Wagle (2009) states while the increasing values of foreign remittance have some positive effects on reducing poverty and income inequality, 
findings suggest that most of the benefits may have favored the socioeconomically more advantaged sections of society (Wagle, U. R. 2009).

All the research studies related with remittance show the impact of remittance income and show the certain relationship with various factors that I want to have the relationship between the income from foreign countries with investment in present condition and is it safe or not? This is the gap I have found in previous literatures.

\section{Research Methodology}

\subsection{Theoretical principle}

In the book 'General Theory of Employment, Interest and Money', Keynes explains investment is related with marginal efficiency of capital and interest rate. If the rate of return from capital assets is less than interest, new investment will not be made. If the expected rate of return exceeds the rate of interest, investment will be made. Again if the current rate of interest is higher, the inducement to invest will be lower (Keynes, 1936). The accelerator theory of investment, in its simplest form, is based upon the notion that a particular amount of capital stock is necessary to produce a given output. According to the neoclassical theory, the desired capital stock is determined by output and the price of capital services relative to the price of output. The price of capital services depends, in turn, on the price of capital goods, the interest rate, and the tax treatment of business income. As a consequence, changes in output or the price of capital services relative to the price of output alter the desired capital stock, hence, investment. Here all the investment theories mentioned above show the relationship of investment with various factors but in this study investment is studied with remittance income for the relevancy of foreign employment.

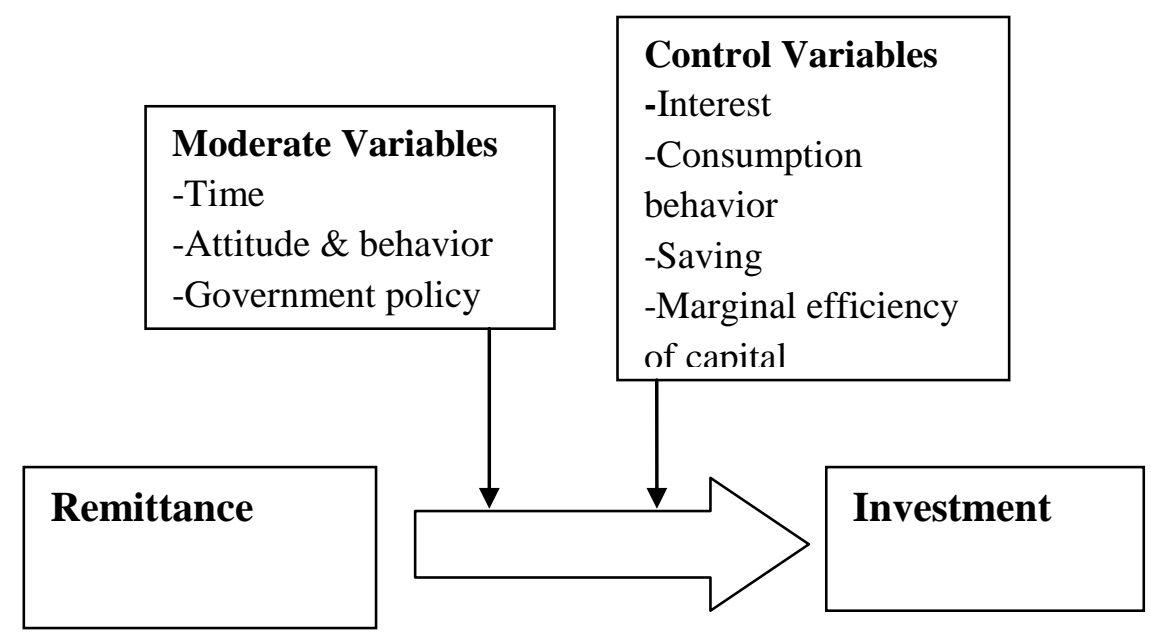


The study will follow post- positivist principle and data from primary and secondary sources are the evidence for the study. This research study is based on time series cross section and panel data available on remittance income and investment. Result is obtained from hypothesis testing of available data and evidence. After all the study will be analytical study.

\subsection{Study Area, Study Population and Sampling}

In this study a major objective of the study is to find out the problem related with foreign employment and compare it with investment in Nepalese context andit will cover all the foreign goers as population of our country. In this study the secondary data is obtained from $2002 / 03$ to $2018 / 19$. Here this study includes the data from economic survey of Nepal 2018/19 for analysis.

\subsection{Data Collection and Analysis}

Here the data is collected from the secondary source to analyze the prevailing condition of foreign employment. Data from economic survey 2018/19 of Nepal are taken for the study which shows the reality of foreign employment in the country.

\section{Findings and discussion}

The given tables describe the picture of the existing condition of foreign employment in time series data that the numbers of foreign employment workers are increasing because there is huge charm of foreign employment in the context of our country and there is no alternative way of employment given or created by the government. A serious fact is that the numbers of death in foreign employment so huge and there is large number of maimed so foreign employment is not so safe but the remittance income is utilized in investment shows that the foreign employment is charming to all but it is totally unsafe but it is used in productive sector anyway.

Country wise Foreign Employment by Details

\begin{tabular}{|c|c|c|c|}
\hline Country's Name & Male & Female & Total \\
\hline Qatar & 51618 & 2421 & 54039 \\
\hline Malaysia & 2651 & 60 & 2711 \\
\hline Saudi Arabia & 26269 & 1150 & 27419 \\
\hline UAE & 36123 & 4742 & 40865 \\
\hline
\end{tabular}


IRJMMC Vol. 1 Issue $1 \quad$ (March, 2020) ISSN 2717-4999 (Online) 2717-4980 (Print)

\begin{tabular}{|c|c|c|c|}
\hline Kuwait & 9020 & 1066 & 10086 \\
\hline Bahrain & 2844 & 273 & 3117 \\
\hline Oman & 1541 & 195 & 1736 \\
\hline Lebanon & 4 & 0 & 46 \\
\hline Israel & 12 & 34 & 1007 \\
\hline Afghanistan & 1003 & 14 & 547 \\
\hline Japan & 498 & 49 & 10374 \\
\hline Other & 7254 & 3120 & $\mathbf{1 5 6 0 9 3}$ \\
\hline Total & $\mathbf{1 4 2 8 2 8}$ & $\mathbf{1 3 2 6 5}$ & \\
\hline
\end{tabular}

Source: Ministry of Labor, Employment and Social Security Foreign Employment

Department.

Number of Death and details of Financial Support

\begin{tabular}{|l|l|l|l|l|}
\hline FY & Male & Female & Total & Amount in 10 thousands \\
\hline $2012 / 13$ & 711 & 11 & 722 & 9.79 \\
\hline $2013 / 14$ & 853 & 24 & 877 & 12.06 \\
\hline $2014 / 15$ & 1000 & 6 & 1,006 & 21.74 \\
\hline $2015 / 16$ & 792 & 24 & 816 & 22.16 \\
\hline $2016 / 17$ & 738 & 18 & 756 & 22.63 \\
\hline $2017 / 18$ & 801 & 20 & 821 & 45.65 \\
\hline $2018 / 19$ & 489 & 15 & 504 & 33.41 \\
\hline
\end{tabular}

Source: Ministry of Labor, Employment and Social Security Foreign employment

Department. 


\section{Details of Ailing, Maimed Nepali Migrant Workers}

\begin{tabular}{|l|l|l|l|l|}
\hline Fiscal Year & Male & Female & Total & $\begin{array}{l}\text { Amount in 10 } \\
\text { millions }\end{array}$ \\
\hline $2012 / 13$ & 87 & 3 & 90 & 0.62 \\
\hline $2013 / 14$ & 108 & 8 & 116 & 0.76 \\
\hline $2014 / 15$ & 181 & 4 & 185 & 1.69 \\
\hline $2015 / 16$ & 112 & 5 & 117 & 1.46 \\
\hline $2016 / 17$ & 198 & 6 & 204 & 2.95 \\
\hline $2017 / 18$ & 356 & 5 & 361 & 6.51 \\
\hline $2018 / 19$ & 170 & 5 & 175 & 4.25 \\
\hline
\end{tabular}

Source: Ministry of Labor, Employment and Social Security Foreign employment Department.

First table shows country wise foreign employment by detail where 142828are male and 13265 female and total 156093 foreign employment workers during the first eight months of FY 2018/19. The highest numbers of foreign workers were for Qatar51618 male and 2421 female in total 54039 workers and the lowest numbers of foreign workers were for Lebanon- 4 male and 0 female in total 4 workers shows the best destination for Nepali migrant workers is Qatar and highest portion of remittance inflow is covered by it where least level of remittance income is received from Lebanon.

Second table shows the number of deaths in foreign country during employment shows 722 death in 2012/13, 877 death in 2013/14, 1006 in 2014/15, 816 in 2015/16 likewise 756 death in 2016/17, 821 deathsin 2017/18 and 504 in 2018/19 in foreign employment show the number of death is so high in foreign employment indicates it is not so safe for foreign goers in spite of the number is decreasing in the recent years.

Final table shows the picture of Ailing and Maimed workers. The data shows 87 male, 3 female and total 90 workers are ailing and maimed in 2012/13. 108 male, 8 female in total 116 in 2013/14, 181 male and 4 female in total 18 in 2014/15, 112 
male and 5 female in 2015/16, 198 male and 6 female in total 204 in 2016/17 likewise 356 male and 5 female total 361 in 2017/18 and 170 male, 5 female in total 175 in2018/19 workers are in ailing and maimed condition. The number of Ailing and Maimed is so high that shows foreign goers have to face many more difficulties in foreign employment and their lives are in risk and not safe.

\section{Estimation}

For the calculation of the relationship between remittance income and investment in the country, the data from 2002/03 to 2018/19are taken and transformed into $\log$ form to run regression analysis. Remittance income from the foreign employment and the investment as the percentage of GDP are transformed into log form and E-Views software is used to calculate the linear regression between the variables. After running regression the following results are obtained.

Analysis of Result:

The individual data are transformed into log form and the relationship between remittance and investment can be figured out as follows. The blue line in the figure shows log form of remittance income and red line shows the log of investment income. Data are taken from 2002/03 to 2018/19 for the study shows the certain relationship between them and log transformation of data can be helpful in reducing heteroskedasticity problem.

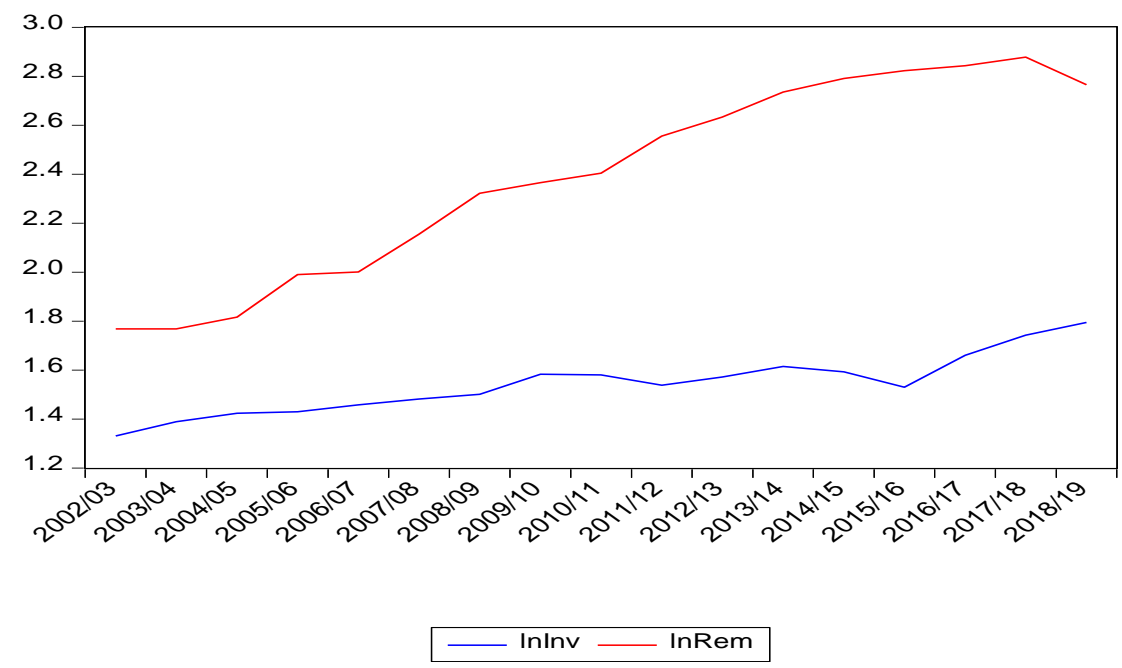

Ordinary least Squares (OLS) are used in a log transformed variables to estimate the influence of remittance in investment and following result can be obtained. The required econometric regression equation is $\operatorname{lnINV}=\alpha+\operatorname{lnREM}+\mathrm{Ut}$

In this study the hypotheses are taken as follows to find out the certain relationship between remittance income and investment in the country. 
Null Hypothesis: H0- There is no significant relationship between remittance income and investment.

Alternative Hypothesis: H1- There is significant relationship between remittance income and investment,

\section{Ordinary least Square Result}

Dependent Variable: LNINV

Method: Least Squares

Date: 03/08/20 Time: 15:01

Sample: 117

Included observations: 17

\begin{tabular}{|c|c|c|c|c|}
\hline Variable & Coefficient & Std. Error & t-Statistic & Prob. \\
\hline $\mathrm{C}$ & 0.919381 & 0.094077 & 9.772605 & 0.0000 \\
\hline LNREM & 0.260760 & 0.038862 & 6.709915 & 0.0000 \\
\hline R-squared & 0.750096 & Mean dependent var & & 1.542299 \\
\hline Adjusted R-squared & 0.733435 & S.D. dependent var & & 0.121674 \\
\hline S.E. of regression & 0.062820 & Akaike info criterion & & -2.586951 \\
\hline Sum squared resid & 0.059196 & Schwarz criterion & & -2.488926 \\
\hline Log likelihood & 23.98909 & Hannan-Quinn criter. & & -2.577207 \\
\hline F-statistic & 45.02296 & Durbin-Watson stat & & 0.897305 \\
\hline Prob(F-statistic) & 0.000007 & & & \\
\hline
\end{tabular}

Here the regression equation becomes $\operatorname{lnINV}=0.919+0.26 \ln R E M+U t$

The table provides regression result of $\mathrm{p}$ - value 0.0000 . Here intercept term is 0.983 and slope coefficient is 0.26 which shows $1 \%$ change in remittance income changes the investment by $0.26 \%$.

Here overall performance level is high with $\mathrm{R}^{2}$ is 0.750 in the model summary implying that $75 \%$ of investment is explained by remittance income and the value of $\mathrm{R}^{2}$ is less than the value of Durbin-Watson stat 0.897305 shows the regression model is not spurious.

The regression significance level is 0.000 which is less than $0.05(\alpha=5 \%)$ shows the model is significant. Here we reject Ho and we have the significant relationship between remittance income and investment that shows the remittance is used in the purpose of investment.

\section{Conclusion}

Data extracted from economic survey is relevant to draw conclusion in the study where null hypothesis is rejected at $\mathrm{p}=0.0000(<5 \%$ level $)$ and the regression is significant and not spurious shows a certain relationship between remittance income and investment where the given data shows the foreign employment is not so safe. 
Nepalese people are forced to go foreign employment due to lack of employment opportunities in home country and labor hard in the foreign country for income generation to fulfill their entire needs and wants without rest. They send their income as remittance in the home country but many researches show this income is only utilized for home consumption not used in further income generation process. But this study of remittance income with investment shows there is certain relationship between them and people are using a small portion of their income from toil, sweat and blood in investment sector even it is not so safe.

\section{References:}

Dhakal, B. P. (2013). Remittance and Its Impact on Education (A Case Study of Gola VDC InBardiya district) (Doctoral dissertation, Central Department of Rural Development Tribhuvan University Kirtipur, Kathmandu, Nepal).

Gaudel, Y. S. (2006). Remittance income in Nepal: Need for economic development. Journal of Nepalese Business Studies, 3(1), 9-17.

Glocker, D., \& Steiner, V. (2007). Self-Employment: Way to End Unemployment? Empirical Evidence from German Pseudo-Panel Data.

Malla, P. S. (2009). Foreign employment and remittance in Nepal. Economic Journal of Nepal, 32(1), 46-60.

Nunley, R. L. (1971). Foreign Employment. Physical therapy, 51(12), 1300-1302.

Sapkota, C. (2013). Remittances in Nepal: boon or bane?. The Journal of Development Studies, 49(10), 1316-1331.

Shrestha, B. (2004). Foreign employment and the remittance economy of Nepal. Nepalese Economy: Towards Building A Strong Economic Nation-State. Kathmandu: Tribhuvan University.

Srivastava, N. L., \&Chaudhary, S. K. (2007).Role of Remittance in Economic Development of Nepal. Journal of Nepalese Business Studies, 4(1), 28-37.

Thagunna, K. S., \&Acharya, S. (2013). Empirical analysis of remittance inflow: The case of Nepal. International Journal of Economics and Financial Issues, 3(2), 337-344

Uprety, D. P. (2017). The impact of remittances on economic development in nepal. Journal of Development Innovations, 1(1), 114-134.

Wagle, U. R. (2009). Experience of Nepali families with foreign remittance: evidence from the Nepal Living Standard Survey.

Wagle, U. R. (2012). Socioeconomic implications of the increasing foreign remittance to Nepal: Evidence from the Nepal living standard survey. International Migration, 50(4), 186-207. 